\title{
Effects of High-Pressure Processing on Toxoplasma gondii Tissue Cysts in Ground Pork
}

Author(s): David S. Lindsay , Marina V. Collins , Daniel Holliman, George J. Flick, and J. P. Dubey Source: Journal of Parasitology, 92(1):195-196. 2006.

Published By: American Society of Parasitologists

DOI: http://dx.doi.org/10.1645/GE-631R.1

URL: http://www.bioone.org/doi/full/10.1645/GE-631R.1

BioOne (www.bioone.org) is a nonprofit, online aggregation of core research in the biological, ecological, and environmental sciences. BioOne provides a sustainable online platform for over 170 journals and books published by nonprofit societies, associations, museums, institutions, and presses.

Your use of this PDF, the BioOne Web site, and all posted and associated content indicates your acceptance of BioOne's Terms of Use, available at www.bioone.org/page/terms_of_use.

Usage of BioOne content is strictly limited to personal, educational, and non-commercial use. Commercial inquiries or rights and permissions requests should be directed to the individual publisher as copyright holder. 
American Society of Parasitology. David S. Lindsay, Marina V. Collins, Daniel Holliman, George J. Flick, and J. P. Dubey (2006). "Effects of High-Pressure Processing on Toxoplasma gondii Tissue Cysts in Ground Pork," Journal of Parasitology, Vol. 92, No. 1, pp. 195-196. doi: http://dx.doi.org/10.1645/GE-631R.1

\title{
Effects of High-Pressure Processing on Toxoplasma gondii Tissue Cysts in Ground Pork
}

\author{
David S. Lindsay, Marina V. Collins ${ }^{\star}$, Daniel Holliman ${ }^{\star}$, George J. Flick ${ }^{\star}$, and J. P. Dubey†, Department of Biomedical Science and \\ Pathology, Virginia Tech, 1410 Prices Fork Road, Blacksburg, Virginia 24061; *Department of Food Science and Technology, Virginia Tech, \\ Blacksburg, Virginia 24061; †USDA, ARS, ANRI, Animal Parasitic Diseases Laboratory, BARC-East, Beltsville, Maryland 20705; e-mail: \\ lindsayd@vt.edu
}

\begin{abstract}
Ingestion of Toxoplasma gondii tissue cysts can result in severe disease in immunocompromised individuals and pregnant women. Treatment of meat and meat products to eliminate viable $T$. gondii tissue cysts would provide a means to protect consumers. In this study, we examined the effects of high-pressure processing (HPP) on ground pork containing viable tissue cysts of the VEG strain of $T$. gondii. Ground pork containing tissue cysts was exposed to 400, 300, 200, 100, or $0 \mathrm{MPa}$ treatment for 30,60 , or $90 \mathrm{sec}$ in a commercial HPP unit. The HPP-treated ground pork was subjected to acid-pepsin digestion and bioassayed in mice. The results of the mouse bioassay revealed that none of the mice inoculated with tissue cysts exposed to 400 or 300 MPa became infected, whereas all mice inoculated with tissue cysts exposed to 200,100, or $0 \mathrm{MPa}$ became infected with $T$. gondii regardless of exposure time. Results indicate that HPP treatment of ground pork with $300 \mathrm{MPa}$ of pressure will render tissue cysts of $T$. gondii nonviable and make pork safe for human consumption.
\end{abstract}

Toxoplasma gondii is a protozoan parasite that infects humans and most other warm-blooded animals. Humans become infected by ingesting meat containing tissue cysts or by ingesting oocysts in the environment. It is estimated that there are 1,500,000 cases of toxoplasmosis in the United States each year and about $15 \%$ of those infected having clinical disease (Mead et al., 1999; Jones, Kruszon-Moran et al., 2001). Congenital toxoplasmosis has long been recognized because of the devastating results it can have on the infected fetus (Jones, Lopez et al., 2001). The relative importance of meat or oocysts as a source of human infection in the United States is unknown.

High-pressure processing (HPP) has been shown to be an effective nonthermal means of eliminating non-spore-forming bacteria from a variety of food products (Tewari et al., 1999; Flick, 2003). The shelf life of the products is extended, and the sensory features of the food are not or only minimally affected by HPP. Other advantages of HPP over traditional thermal processing include reduced processing times, minimal heat damage problems, retention of freshness, flavor, texture, and color; no vitamin $\mathrm{C}$ loss; no undesirable changes in food during pressure-shift freezing because of reduced crystal size and multiple icephase forms; and minimal undesirable functionality alterations (Tewari et al., 1999).

Little has been published on the effects of HPP on parasites in food Ohnishi et al. $(1992,1994)$ determined that pressures of greater than 200 MPa kill 8-wk-old Trichinella spiralis larvae. Gamble et al. (1998) determined 55-60 MPa did not kill all $T$. spiralis larvae in pork tenderloin or diaphragm. Treatment at $200 \mathrm{MPa}$ for $10 \mathrm{~min}$ at temperatures between 0 and $15 \mathrm{C}$ kills Anisakis simplex larvae, with a lack of motility being used as an indicator of larval death (Molina-Garcia and Sanz, 2002). Dong et al. (2003) found that times and pressures required to kill $100 \%$ A. simplex larvae in king salmon and arrowtooth flounder were 30-60 sec at $414 \mathrm{MPa}, 90-180 \mathrm{sec}$ at $276 \mathrm{MPa}$, and $180 \mathrm{sec}$ at $207 \mathrm{MPa}$. Slifko et al. (2000) examined the effects of $550 \mathrm{MPa}$ on Cryptosporidium parvum oocysts in apple and orange juice. They determined that a $60-\mathrm{sec}$ exposure at $550 \mathrm{MPa}$ was $100 \%$ effective in decreasing infectivity of oocysts for cell cultures.

The brains from 6 mice having tissue cysts of the VEG strain of $T$. gondii (Dubey et al., 1996) were shipped by overnight carrier from the Animal Parasitic Diseases Laboratory, Beltsville, Maryland, to the Center for Molecular Medicine, Virginia Tech, Blacksburg, Virginia. The brains were mixed with ground pork until a 60 -g sample was present. Brains and pork were mixed manually with a spatula for approximately $5 \mathrm{~min}$. The ground pork had been purchased commercially and had been frozen at $-80 \mathrm{C}$ for 2 days to kill any $T$. gondii tissue cysts that might have been present. Four grams of the pork and mouse brain mixture were placed in plastic bags and used for each treatment. Four grams of the source ground pork was not mixed with mouse brains and was used as a negative control. The bags were compressed to force out air and to obtain a uniform thickness of 3-4 $\mathrm{mm}$. The bags were then sealed with a sealing machine. The bags were placed in additional bags and vacuum-sealed. The vacuum-sealed bags containing pork-mouse brain mixture were used for HPP. Two days elapsed between killing of $T$. gondii mice infected with the VEG strain, treatment with HPP, and mouse bioassay; during this time, materials were kept cold (4-10 C).

Table I shows the pressures and exposure times examined in the HPP study. The bags were placed into a commercial HPP unit (Quintus Food Press QFP 35 L-600 model, Flow International Corporation [Avure Technologies], Kent, Washington) with a 7XS-6000-intensifier pump and a maximum operating pressure of $600 \mathrm{MPa}$. The HPP unit was installed and operated at Virginia Tech's Department of Food Science and Technology.

Samples of HPP-treated and control ground pork were shipped to the Animal Parasitic Diseases Laboratory, Beltsville, Maryland, on cold packs by overnight express courier. Samples were digested in acidpepsin solution and bioassayed in groups of 4 mice as described (Dubey, 1998). Mice were inoculated subcutaneously in the dorsal scapular region with digested ground pork. During the study, impression smears were made from the brains or lungs of any mice that died and were examined unstained by light microscopy for tachyzoites. At 6 wk postinoculation, all surviving mice were bled from the retro-orbital plexus. The serum was collected and examined for antibodies to $T$. gondii in a modified direct agglutination assay (MAT) (Dubey and Desmonts, 1987). The mice were killed 43 day postinoculation, and brain squashes of all mice were examined for tissue cysts, irrespective of serologic data (Dubey and Beattie, 1988). Mice were considered negative if they had a negative MAT and no tissue cysts were seen in their brains. Mice were considered positive when $T$. gondii was demonstrable in tissues.

None of the mice inoculated with noninfected control ground pork became infected with $T$. gondii (Table I). All mice inoculated with non-

TABLE I. Efficacy of high-pressure processing of ground pork containing Toxoplasma gondii tissue cysts on the infectivity of tissue cysts for mice.

\begin{tabular}{ccc}
\hline Treatment (MPa) & Exposure time (sec)* & $\begin{array}{c}\text { No. of mice inoculated/ } \\
\text { No. of mice positive }\end{array}$ \\
\hline 400 & 30 & $4 / 0$ \\
400 & 60 & $4 / 0$ \\
400 & 90 & $4 / 0$ \\
300 & 30 & $4 / 0$ \\
300 & 60 & $4 / 0$ \\
300 & 90 & $4 / 0$ \\
200 & 30 & $4 / 4$ \\
200 & 60 & $4 / 4$ \\
200 & 90 & $4 / 4$ \\
100 & 30 & $4 / 4$ \\
100 & 60 & $4 / 4$ \\
100 & 90 & $4 / 4$ \\
0 & NA & $4 / 4$ \\
$0 \dagger$ & NA & $4 / 0$ \\
\hline
\end{tabular}

* NA $=$ not applicable.

$\dagger$ Negative control sample did not contain tissue cysts. 
pressure-treated $T$. gondii tissue cyst containing ground pork became infected. Treatment of $T$. gondii containing ground pork with HPP at 300 or $400 \mathrm{MPa}$ for $30 \mathrm{sec}$ or longer completely eliminated infectivity for mice (Table I). Treatment of $T$. gondii containing ground pork with $\mathrm{HPP}$ at 100 or $200 \mathrm{MPa}$ for $90 \mathrm{sec}$ did not eliminate infectivity for mice (Table I).

The results of this study indicate that HPP can be used to render meat products free of viable $T$. gondii tissue cysts. Humans and other hosts can also become infected with $T$. gondii by ingesting oocysts in contaminated food or water. Oocysts treated with HPP for $60 \mathrm{sec}$ at 550 , 480 , 400, or $340 \mathrm{MPa}$ for $60 \mathrm{sec}$ were rendered noninfectious for mice (Lindsay et al., 2005). Oocysts treated for $60 \mathrm{sec}$ with HPP at 100, 140, 200 , or $270 \mathrm{MPa}$ for $60 \mathrm{sec}$ were infectious for mice (Lindsay et al., 2005).

This study was financially supported in part by an Animal Health and Disease grant to D.S.L. and G.J.F. We thank Laura S. Douglas for her help with HPP treatment operations.

\section{LITERATURE CITED}

Dong, F. M., A. R. CoOK, And R. P. Herwig. 2003. High hydrostatic pressure treatment of finfish to inactivate Anisakis simplex. Journal of Food Protection 66: 1924-1926.

Dubey, J. P. 1998. Refinement of pepsin digestion method for isolation of Toxoplasma gondii from infected tissues. Veterinary Parasitology 74: 75-77.

, AND C. P. Beattie. 1988. Toxoplasmosis of animals and man. CRC Press, Boca Raton, Florida, 220 p.

- AND G. DESMONTS. 1987. Serological responses of equids fed Toxoplasma gondii oocysts. Equine Veterinary Journal 19: 337 339.

- J. K. Lunney, S. K. Shen, O. C. H. Kwok, D. A. Ashford, AND P. Thulliez. 1996. Infectivity of low numbers of Toxoplasma gondii oocysts to pigs. Journal of Parasitology 82: 438-443.

FLICK, G. J., JR. 2003. High pressure processing offers varied applications. Global Aquaculture Advocate 6: 82-85.
Gamble, H. R., M. B. Solomon, And J. B. Long. 1998. Effects of hydrodynamic pressure on the viability of Trichinella spiralis in pork. Journal of Food Protection 61: 637-639.

Jones, J. L., D. Kruszon-Moran, M. Wilson, G. McQuillan, T. Navin, AND J. B. MCAuley. 2001. Toxoplasma gondii infection in the United States: Seroprevalence and risk factors. American Journal of Epidemiology 154: 357-365.

, A. Lopez, M. Wilson, J. Schulkin, And R. GibBs. 2001. Congenital toxoplasmosis: A review. Obstriatric and Gynecological Survey 56: 296-305.

Lindsay, D. S., M. V. Collins, C. N. Jordan, G. J. Flick, and J. P. DuBEY. 2005. Effects of high pressure processing on infectivity of Toxoplasma gondii oocysts for mice. Journal of Parasitology 91: 699-701.

Mead, P. S., L. Slutsker, V. Dietz, L. F. Caig, J. S. Bresee, C. Shapiro, P. M. GRIfFin, AND R. V. TAuXe. 1999. Food-related illness and death in the United States. Emerging Infectious Diseases 5: 607624.

Molina-Garcia, A. D., And P. D. SAnz. 2002. Anisakis simplex larva killed by high-hydrostatic-pressure processing. Journal of Food Protection 65: 383-388.

OHnishi, Y., T. OnO, AND T. SHIGeHISA. 1994. Histochemical and morphological studies on Trichinella spiralis larvae treated with high hydrostatic pressure. International Journal for Parasitology 24: 425-427.

,-- , AND T. OHMORI. 1992. Effect of high hydrostatic pressure on muscle larvae of Trichinella spiralis. Japanese Journal of Parasitology 41: 373-377.

Slifko, T. R., E. Raghubeer, And J. B. Rose. 2000. Effect of high hydrostatic pressure on Cryptosporidium parvum infectivity. Journal of Food Protection 63: 1262-1267.

Tewari, G., D. S. Jayas, and R. A. Holley. 1999. High pressure processing of foods: An overview. Science Des Aliments 19: 619661 .

\section{Use of Trichomonas vaginalis Clinical Isolates to Evaluate Correlation of Gene Expression and Metronidazole Resistance}

J. R. Mead ${ }^{\star} \dagger$, M. Fernadez ${ }^{\star} \dagger$, P. A. Romagnoli ${ }^{\star} \dagger$, and W. E. Secor $\neq,{ }^{*}$ Veterans Affairs Medical Center, Decatur, Georgia 30033; $† E m o r y$ University School of Medicine, Department of Pediatrics, Atlanta, Georgia 30022; łDivision of Parasitic Diseases, National Center for Infectious Diseases, Centers for Disease Control and Prevention, Atlanta, Georgia 30341; e-mail: jmead@emory.edu

ABSTRACT: We investigated whether variations in gene expression of enzymes associated with anaerobic resistance of laboratory-derived strains of Trichomonas vaginalis could be detected in a group of 28 clinical isolates with variations in metronidazole sensitivity. We compared isolates by real-time PCR because this method allows for highly sensitive quantification of mRNA and for evaluation of several genes simultaneously. We found that PFOR gene A mRNA levels were highly correlated with PFOR gene B levels, as well as the D subunit of malic enzyme and ferrodoxin. Ferrodoxin mRNA expression was also significantly correlated with that of malic enzyme and hydrogenase. However, when we evaluated relationships between these enzymes and resistance to metronidazole, we found no significant correlations between aerobic or anaerobic in vitro sensitivity to drug and mRNA levels of any of the enzymes tested. Similarly, using a Student's $t$-test, no significant differences in enzyme mRNA levels were observed between isolates separated by metronidazole resistance or susceptibility. The lack of correlation between gene expression and resistance or susceptibility could be the result of differences in expression at the protein level or because other biochemical pathways or genes are involved in the resistance observed in clinical settings.
Trichomonas vaginalis is a parasitic protozoan that causes the sexually transmitted disease known as trichomoniasis. Estimated annual incidence of trichomoniasis is over 8 million cases in North America and more than 170 million infections worldwide (Petrin et al., 1998). Trichomonas vaginalis infections in women range from an asymptomatic carrier state to an acute, inflammatory disease of the genital tract and have been associated with preterm labor and associated low birth weights. In males, $T$. vaginalis can cause urethritis and prostatitis. In addition, trichomoniasis is also associated with increased HIV transmission (Sorvillo and Kerndt, 1998; Buve et al., 2001; Chesson et al., 2004).

The 5-nitroimidazoles, especially metronidazole, are the most widely used antimicrobial agents for the treatment of trichomoniasis. However, metronidazole resistance is an increasingly recognized problem in treating patients infected with trichomoniasis (Sobel et al., 1999). Metronidazole enters the parasite by passive diffusion as a nonlethal prodrug. Once inside the cell, metronidazole is reduced, resulting in the generation of nitro radicals, which lead to DNA damage and cell death. Trichomonas vaginalis cells use pyruvate-ferrodoxin oxidoreductase (PFOR) and ferrodoxin-linked enzymes to metabolize pyruvate to acetate via 